International Journal of English Literature and Social Sciences
Vol-6, Issue-1; Jan-Feb, 2021

\title{
The Highlighting of Gender-Parity and Male Hectoring in Hemingway's For Whom the Bell Tolls (1940)
}

\author{
Amir Baradaran (M.A.) $)^{1}$, Omid Ghahreman (Ph.D) ${ }^{2}$ \\ ${ }^{1}$ Department of English Literature, Khayyam University of Mashhad, Iran \\ amirbaradaran.ab@gmail.com \\ ${ }^{2}$ Assistant Professor, Department of English Literature, Khayyam University of Mashhad, Iran \\ o.ghahreman@khayyam.ac.ir
}

Received: 19 Nov 2020; Received in revised form: 30 Jan 2021; Accepted: 09 Feb 2021; Available online: 25 Feb 2021

(C)2021 The Author(s). Published by Infogain Publication. This is an open access article under the CC BY license

(https://creativecommons.org/licenses/by/4.0/).

\begin{abstract}
For Whom the Bell Tolls (1940) is a Hemingway's masterpiece based on his own experiences of the Spanish Civil War. The novel tells the story of an anti-fascist Spanish group of guerillas which the American protagonist, Robert Jordan, joins in order to blow up a bridge. The only two women among the characters, Pilar and Maria, represent matching and also different views on female gender roles in the male-dominated environment. The present study employs the ideas of Sara Mills, the English scholar on Linguistic Feminism and draws a feminist analysis on gender roles and the use of sexist language in For Whom the Bell Tolls (1940). The article concludes that although Maria and Pilar stand on far extremes of femininity, both are challenged with the male preferential language and sexist pejoration.
\end{abstract}

Keyword-Earnest Hemingway, Feminism, Linguistics, women, sexism, Sara Mills.

\section{INTRODUCTION}

The American novelist, Earnest Hemingway (1899-1961) is widely known around the world for his brilliant style and flawless descriptions, his contributions to journalism, and his special attention to the thin and easily flowing detailing. For Whom the Bell Tolls (1940) had been inspired by John Donne's (1623) famous saying: "never send to know for whom the bells tolls; it tolls for thee."(p.109)

As suggested by John Donne, the phrase explains the view toward death as an imminent incidence which happens for everyone and the church bell, which announces it, does not clang for the dead but for the living, informing that the next death is about to come.

Hemingway left America to join the Spanish Civil War (1936-1939) as a journalist. The war started due to the dispute among different Spanish political parties and factions fueled by their attempts to overthrow the already ruling democratic regime. All of the fighting groups were standing on two main sides: the Nationalists (Christian Catholics, fascists, anti-communists, etc.), and the Republicans (Marxists, anarchists and so on). According to Carter (2013) 'as several biographers have noted, he [Hemingway] was drawn to the war not just by a love for Spain, but also, at least in part, by a desire to prove that he was man enough to take on a war' (pp. 2-4).

Having experienced the everyday life and wonderful culture of Spanish people, Hemingway fictionalized his experiences of presence in the Spanish war zone in his novel. The novel narrates the story of the American dynamiter, Robert Jordan, who joins the antifascist Spanish guerillas and is going to blow up a certain bridge. Other major characters are Pablo, the leader of the nuclear group; Pilar, his wife; Anselmo, Jordan's assistant; and Maria, the young Spanish woman who then engages in a love affair with Robert Jordan. One of the recurrent highlights of For Whom the Bell Tolls (1940) is these two 
women's interaction with other male characters in terms of language, behavior, gender roles and romance-based affairs. Stereotypically, the war veterans including the protagonist are all male, but female characters 'are forced to adapt to an evolving gender-role system' (Derek, 2017, p. 3). Hemingway, known by many as 'a deeply conflicted but ultimately patriarchally grounded man and writer' (Hewson, 2004 , p. 171) portraits women in his novels in a maleoriented atmosphere and to some extent uses sexist language.

Sara Mills, the feminist scholar, has explored thoroughly the multi-layered cultural and social issues concerning linguistic aspects of sexist preferences and longwinded semantic differences in human language mainly in Language and Sexism (2008). Her interlinear approach, forwardness and much informed feminist style, has made her an outstanding academician in feminist studies and could best help achieve the objective of this study.

Tellingly, femininity and masculinity, the two terms which are going to be compared and contrasted in this article, do not forcefully confine members of a society to fit these two spheres. These two terms only depict the characteristically extreme visible codes of conduct and main qualities which are mostly noticeable and evidently common in men and women. Certainly, descriptions like "patriarchal woman," "matriarchal man," "masculine woman," and "feminine man" are to be understood within the realm of academic interpretation. Therefore, non-discursive practices are to be avoided in order to fulfill the objectives of this study.

\section{METHOD}

Sara Mills' literary explorations have been published in many books and articles among which Language and Sexism (2008) is the one whose extended texture and flowing language informs the readers of the feminist philosophy from a linguistic perspective. After giving an introduction to the Second and the Third Wave feminism, she extends that her approach is more oriented toward the latter which comes as a development from the former, and sees 'gender difference and gender identity as socially constructed rather than as originating in biological difference' (Mills, 2008, p. 22). So the Third Wave feminism focuses mostly on the social aspects of gender relations and not biological differences which are already accepted as having been performing within the realm of their consequences.

Mills (2008) categorizes different types of sexism as direct and indirect and explains their social and cultural notions and also their disputing functions and involvements with both men and women. She states that:

Sexism is not just about statements which seem to excessively focus on gender when it is not relevant, ... statements may be considered to be sexist if they rely on stereotypical and outdated beliefs, when referring to a particular woman ... it is assumed that the woman referred to is exhibiting behaviour which is typical of feminine women and therefore she is being classified less as a person in her own right, with her own feelings, but rather as simply an anonymous member of a social group ... A further factor in statements being considered sexist is when they imply that men's experience is human ... [also] when they are based on the presupposition that any activity associated with women is necessarily trivial or secondary in relation to male activities. (p. 2)

Thus, in the novel, the minority group of women (of two) among the major characters is considered to be looked upon through different sexist attitudes of male warriors. Moreover, these women are characteristically different from each other (for example in terms of responding to their sexist male environment), so they pick up contrasting strategies of their own. In addition, according to their own oppositely functioning individual views and beliefs about personality, gender roles and traditions, these two women take in and interpret sexism, both in direct and indirect forms. As Deborah Cameron (1990) believes, sexist language is better being analyzed as a multifarious appearance rather than mere masculinist names and titles (p. 14).

As a result, it might seem unfair to put all the burden of unbalanced sexism on the shoulder of characters individually; so the aim of this study would be to stay away from accusations and approbations and instead highlight the overt and hidden sexism thorough the novel in order to calibrate a more sophisticated view toward gender-parity and inculcate in readers an egalitarian approach and an attitude of equalitarianism. As Ainsworth and Hardy (2004) believed: 'Discourse does not transparently reflect the thoughts, attitudes and identities of separate selves but is a shared social resource that constructs identity as individuals lay claim to various recognizable social and shared identities' (p. 237).

\section{DISCUSSION}


Much more than mere labelings and title-givings, looking at a text through a critical discourse builds on its referenceability. Many Critics believe that Hemingway's woman characters represent subservience and docility or, on the other side, danger and malignance. As Gail D. Sinclair (2002) states: 'On their surface, texts such as For Whom the Bell Tolls (1940) had established Hemingway's manly hero and offered versions of his standard female types: the submissive dream girl or the castrating (though sometimes maternal) bitch' (p. 93). Similarly, Arthur Waldhorn believes that 'Hemingway's women either caress or castrate' (qtd. in Sinclair, 2002, p. 95).

\section{1. Gender Roles and Traditional Descriptions}

After Robert Jordan's acquaintance with the Spanish guerillas is introduced, we see him as he sits down to rest and for the first time he meets Maria and a little later Pilar (Hemingway, 1940, p. 24). Hemingway describes Maria with artistic similes to emphasize her beauty, but contrastingly, when he describes Pilar, not as beautiful as Maria, he makes bright comparisons between her and her husband, Pablo, stating that she is manly (p. 32). The use of adjectives like 'big,' 'wide,' 'tall' and 'thick' directly refer to her masculine appearance considered to be unattractive for Robert Jordan. The masculinity of Pilar, then resultantly her treatment as a less feminine figure, is introduced as the sole reason of her ugliness so the male/female binary is made on extreme opposing qualities. However, it is generally accepted that in ancient times, women and men categorically had more distinguished tasks and therefore represented distant gender roles, but little by little the intermingling of those duties has caused at least a part of the sexist conflicts. Accordingly, it is not wrong to claim that, in the novel, women are engaged in a traditionally male-suited occupation such as war and fighting, which Carter (2013) calls a 'hypermasculinized theatre' (p. 4). This change of place is the locus of sexist remarks. As Mills (1987) suggests, it should be noticed that 'as with everything which is labelled masculine or feminine, I would argue that these terms have very very little to do with the biological sexes, but a great deal to do with assertions of power' (p. 197).

According to Mills (2008): 'In the past women and men had more clearly defined separate roles and spheres, and, for many men and women, this lack of distinction is troubling, hence the necessity to assert sex difference as binary and natural' (p. 73). A major concern here might be that of 'distinction' which Hemingway considers artistically as the troublesome notion of gender roles. Women who might have been stereotypically known as supporters behind the line, and now they are at the front fighting with men, might, of course, not show the same soft and homely appearance. But a biased distinction is held here encircling a large bodied powerful woman as a man, thoroughly neglecting her personal feminine identity. In an interview, Sara Mills states that: 'Discrimination is often not as direct and blatant as it was, and just as we needed in the past to make those indirect forms of discrimination plainly visible' (Van der Bom \& Mills, 2018, p. 126).

The opposite sexist 'distinction' happens about Maria when 'Robert Jordan reached his hand out and patted her head. She stroked under his hand like a kitten. Then he thought she was going to cry. But her lips drew up again and she looked at him and smiles' (Hemingway, 1940, p. 71). Associating women with softness, submissiveness and sensitivity is another pre-defined attitude considered to be positive in their relationship with men. The male attitude toward both Pilar and Maria is sexist, the former mockingly and the latter approvingly. It might be considered a false opposition to put Maria in front of Pilar in terms of "femininity". Apparently, it would explain their characters more respectfully if they are referred to in terms of "femaleness" instead, the quality both of which carry in themselves. Notions of "female masculinity" [and also maybe masculine femininity] give men and women a wider scope of behavior and enlarges gender role circles as to prevent them from defining themselves on edge from time to time: 'One can be a woman without necessarily considering oneself to be (or others considering one to be) feminine' (Mills, 2008, p. 130).

On the other side of the coin, in the story sexism also hunts men, who lack traditionally accepted male qualities, such as courage, leadership, and directness. They are also called as women by insultingly negative adjectives which express sexist attitudes.

\section{1. 1. Male/Female Binary}

Undoubtedly, men and women are both defined in opposition to each other. So deviating from a set of traditional behavior would possibly result in sexist insults. It might be argued that 'because of changes in men's and women's employment patterns and involvement in the public sphere, together with the impact of feminism, there is a sense in which men, at least at a stereotypical level, are often represented as in crisis about their masculinity' (Mills, 2008, p. 131). This "masculinity crisis" sprouts among the guerillas when Pablo states firmly that he is the commander of their 
group, and Pilar stalwartly rejects his claim and asserts her position as the commander (Hemingway, 1940, pp. 59-60).

Another example would be when Jordan comes back from his strategic exploration of the environment to the cave of guerillas and Maria hurries to help him warm up his feet. Jordan smiles and says:

'Thou canst not dry them with thy hair?' he said for Pilar to hear.

'What a swine,' she said. 'First he is the Lord of the Manor. Now he is our ex-Lord Himself. Hit him with a chunk of wood, Maria.'

'Nay,' Robert Jordan said to her. 'I am joking because I am happy.' (Hemingway, 1940, p. 211)

A slight commotion is excited between Jordan and Pilar as a result of Jordan's joking with Maria. Although the reader might see this as a joke, notions of sexism work doubly oppressive here; at first Jordan jokes with Maria for questioning the matriarchal power of Pilar, and then in order to defend her own power, Pilar provokes Maria to hurt Jordan. Among these three, the most obvious subject of sexism is Maria, who not only does not respond back, but also she continues to warm Jordan up primly and keeps silent.

\subsection{Patriarchal Expectations}

\section{2. 1. The Past and Virginity}

Long before she finds shelter in the cave of guerillas, Maria was sexually harassed by fascist soldiers who killed her parents and occupied her village. The sad story of Maria's rape could be analyzed in two levels: her own individual psychology in particular, and her society and female oppression in general. Certainly, the rape left a great traumatic experience in her mind which holds in her a resisting sadness. And socially, Maria sounds apologetic when she refers to her loss of virginity in front of Robert Jordan. There are, for sure, internalized patriarchal values submitted to her mentality, and she is following them unquestioningly. However, it should be noticed that patriarchal values are a subcategory of Maria's own feminine codes of conduct from which one may not easily interpret a pure femininely defined mindset. Accordingly, the shame, upon which Maria looks as the remnant of her washed honor, is basically a reference to her entire life, aimed at satisfying the male characterization of the pusillanimous woman who keeps herself untouched until marriage.
When Maria and Robert Jordan tell each other about their emotions while cuddling in Jordan's sleeping bag, the question of the "past" is introduced first by Robert Jordan: 'Hast thou loved others?' (Hemingway, 1940, p. 74). Maria's answer is a direct negative, but she tells Jordan that she had been sexually harassed and raped during the war, and Jordan seems to become really upset by that. Later in the novel, Jordan's past is explained, that he has known many women but not seriously. Although Maria's rape victimization happened when she was not committed to Robert Jordan, she tries unstoppably to explain that she resisted the rape, even when Jordan does not ask her to insist and reassure him.

Evidently, Maria, who shares her name with Virgin Mary, tries to keep on attaching herself with patriarchal values which are intertwined with tradition and to some extent, Christianity (Hewson, 2004, p. 181). This matter extends through the novel and again Maria opens the subject of her rape by the fascists but this time in detail. Jordan then tries to soothe her while being angry and disgusted inside (Hemingway, 1940, p. 367).

Depicted as an infantilized woman who is in desperate need for protection, Maria then asks Jordan if they could kill those people in war. Jordan's hatred and Maria's lack of power come together to create the sexist atmosphere of rage between men. Surprisingly enough, Maria is shown as an indecisive subject who does not possess the power to resist rape, does not have the strength to show a backlash without a man, and believes that her loss of virginity is only explainable through female victimization and not a war wound, or, least of all, matter of personal life. Although these all happened in the past when Jordan could not be present to help, the sexist language of Maria excessively provokes Jordan. Perhaps he sees himself responsible for an all-time-awake protection of his powerless female partner. Moreover, giving a higher voice to the indirect sexist narrative of Maria's rape, Carter (2013) argues that 'the attack on Maria proves that woman are subject to retaliatory sexual violence when they get too close to interfering with the traditionally masculine realm of politics/war' (p. 24).

Jordan in his thoughts then continues to sulk and occupies himself with reasons to answer why the fascist did so to Maria: " Otra Virgen mas. I suppose that was why they had to destroy the virgins or their enemies. Surely it was deeper with them, with Spanish religious fanatics, than it was with the people" (Hemingway, 1940, p. 368). As a matter of fact, Jordan justifies this cruel obligatory rape as a damage done to the beliefs of religious hardliners; a 
detrimental harm which signifies the occupation of the virgin Spain by fascists in general, which puts the concept of motherland under the heavy shade of insult. Evidently, the sexist language goes insolently further as to involve matters of patriotism (Carter, 2013, p. 16).

Mills (2008) smartly argues that 'it must be the case that when there is a named category for a particular experience, that experience itself begins to feel more acceptable, or at least is more commonplace if you do not have to explain the experience in phrases developed from scratch' (p. 86). The insistence, on which Maria is putting emphasis, might be said to have arisen from her internalized responsibility of keeping the female body virgin before marriage. In spite of losing it in war and not in a romantic affair (had it been done, it would still be personal), she still keeps reasoning to cancel the equation of virginity to chastity.

Maria, who might also stand as a metaphor for Spain, is loved by Jordan (although in both reality and in the story America is not involved in the Spanish Civil War). Hence moving away from sexism, Alfred Kern (2005) justifies this as Hemingway's personal love for Spain and its culture claiming that not being involved in Marxist incentives or left/right wings, the protagonist of the novel fights only for Spain (p. 151).

It might be claimed that Hemingway was not involved in "overt sexism"; however, several sexist allusions (likening Maria to the oppressed and invaded land of Spain) cast a big enough shadow of "indirect sexism" on the novel's narrativity. Moreover, speaking of direct sexism, Jordan's calling Maria a 'rabbit' is a resonant example of male sexualization. Robert Jordan, who is a Spanish teacher at university, calls Maria by nicknames like 'Rabbit' and 'Guapa'. In Spanish, the former 'is conejo [rabbit, an animal], also the common Spanish slang for cono, or cunt' (Eby, 1998, p. 206), and the latter 'A slang-word for female genitalia!' (Brenner (1992), qtd. in Carter, 2013, p. 34).

Certainly subjected to further scrutiny, it takes pains to avoid the idea that Jordan meant "Rabbit" in English and not Spanish, but calling Maria 'Guapa' does not leave any doubt in using negative lexicon against Maria even in his inner sanctum. After all, presenting a caveat, Sinclair (2002) believes that: 'Textually, the term seems one strictly of endearment and not derogation' (p. 107). Thus, entering the realm of interpretation, one might find a widely believed sexist remark, not sexist at all.
It is not wrong to say that indirect sexism is more arguable in comparison to overt sexism because it involves matters of interpretation. In the novel, it is emphasized that Jordan pays most of his attention to his duty as a dynamiter. Although he loves Maria wholeheartedly, at times he stays away from her personality and the echoing of his sexualizations drowns out her individual personality. In lieu of paying attention to her, he might be trying to pacify his stress and anxiety by the act of having sex because of his preoccupation with war and bridge blowing.

\section{2. 2. Beauty vs. Ugliness}

On a short journey in the mountains, Robert Jordan, Maria and Pilar rest for a while and Pilar talks about how she does not like her mountainous environment. Jordan then asks her why she refuses to go somewhere else and she replies:

'...with this face? This is a fact that is known ... I'm not ugly. I was born ugly. All my life I have been ugly. You, Ingles, who know nothing about women. Do you know how an ugly woman feels? (Hemingway, 1940, pp. 102-103)

The conversation continues between the three, and Pilar tells them that many gentlemen callers have loved her, because they had become blind by "idiotic" feelings and when the truth had been uncovered, they knew that she is ugly and left her. Moreover, Pilar shows her jealousy of Maria's beauty and young girl's uncontrollable emotions for Robert Jordan. Psychosexually, Pilar also feels envious that instead of Maria, she could not win the attention of the new male guest, Robert Jordan (Hemingway, 1940, pp. 161-163)

It should be mentioned that language does not immediately refer to 'social values' and is not a 'catalyst for social change' but because of its importance in shaping social definition and gender roles, it reveals a society's inner notions (Mills, 2008, p. 18). The notions are the reified inculcation of male-oriented gender roles both for men and women. Trying hard each in her own way to satisfy the female social and cultural preferential patterns of patriarchy, Pilar and Maria both feel an uneasiness inside: Pilar for being ugly and not noticeable by men, and Maria for not being an untouched feminine figure. The former acts as a supportive leader and the latter acts as a vulnerable woman who is in desperate need for Jordan's love and protection. The way they are addressed in the novel certainly leaves no agency for them to define their own individual femininity so that the notion of definition which is the question of agency here is to a great extent shadowed by masculinity.

\section{2. 3. Men vs. Men}


The commonsensical definition of gender roles also entraps men by exposing them to a crisis in masculinity. For example, Pilar tells the story of Pablo's brutality when they killed lots of fascists and occupied a town, and she wonders how he has lost his barbaric side which is a must for a man (Hemingway, 1940, pp. 105-136). It becomes evident that before Pilar became committed to Pablo, she was with Finito De Palencia, a Spanish matador. While others are listening, Pablo talks about Finito in a ridiculing manner. Pilar becomes upset and defending her ex-lover defines him in terms of brevity and manliness. Also she boasts about his sex drive to impersonate Pablo for having changed from a barbaric violent man, whom she admired as a masculine figure, to a coward (Hemingway, 1940, p. 190).

\section{3. Care and Assistance}

Throughout the novel, Maria assists Jordan in his routine tasks and insists on taking care of him lovingly. She tells Jordan: 'I will learn from Pilar what I should do to care of a man well and those things I will do...Then, as I learn will discover things for myself and other things you can tell me' (Hemingway, 1940, p. 177).

Maria's referring to the matriarch of the Spanish group, Pilar, saliently suggests her influencing role on Maria who abides by her rules. Surprisingly, when Robert Jordan is thinking, he tells himself, that: 'When you get through with this war you might take up the study of women, he said to himself. You could start with Pilar' (Hemingway, 1940, p. 183) which shows his mental occupation with this ruling woman.

Pilar and Maria take the responsibilities of cooking and cleaning and the wellbeing of the male warriors to a great extent. As Mills (2008) believes, sexism is more likely to be practiced inside certain communities. Thus, sexism is going to act as a kind of user tag (p. 33). Some of these tags might indirectly associate the user to a certain community which s/he does not appreciate (p. 37). That might best bolster the sexist attitudes of all the character, including the two women, that Maria should do the cooking and cleaning.

The notion of sexism becomes doubly highlighted when the two women characters of the novel join the male hectoring as patriarchal women and do the female oppression along with men and against themselves. This is not only recognized here as normal, but also it is cherished, and not debriefed by the female characters. Apparently, they have internalized their oppressed self as naturally acceptable.

It might be a sexist idea, indicating that men and women no matter what responsibilities they carry, must fulfill certain gender roles. Accordingly, the problem of sexist language becomes twofold, one which is the oppressing of women and denigrating their social status, and another which is the matter of interpreting the existing (and probably accepted) gender roles which are defined freehandedly for men, but more restrictedly for women; possibly as a result of abiding by the rules of male-explicated language.

\section{4. Marriage and Patriarchal Authority}

\section{4. 1. Tradition}

From time to time, marriage becomes a subject for conversation between Maria and Robert Jordan. In the story, Jordan is introduced as an archetypal protector, and Maria the traditional object of protection who believes that her commitment to Jordan is taken for granted while his commitment to her emotional concerns should be asked for. In the second half of the novel, Maria tells Jordan about her happiness after knowing that he has never been married. Contrastingly, she is happy that Jordan has been with a lot of women and tells him about Pilar's idea: good husbands are the ones who have been with many women (Hemingway, 1940, pp. 357-358). Seemingly, the woman has been advised to keep a man-free history while the more women a man could be with, the more implicatures of masculinity and power are observed.

Presenting a caveat, Carter (2013) argues that Maria: 'has been almost entirely ignored or dismissed outright, especially by feminist critics who tend to view her as one of Hemingway's submissive dream girls. I would argue that there is another possibility for interpreting Maria, one that is deeply enriched by a familiarity with trauma theory' (p. 7). Maria's over-reliance on masculinity and over-emphasis to draw upon patriarchal values might be a response to her traumatic past (to which she answers with resilience) and not simply representing an underestimated male-dominated woman. Carter (2013) believes that Maria is not 'obedient' but 'she is an active fighter' and in spite of being expressive 'she is consistently silenced' by others. Also in terms of sexuality, she is an active female character who 'is trying to come to grips with her sexuality after sex has been used as a retaliatory weapon against her for getting too close to the male sphere of political battle' (p. 7).

Having been carrying her trauma of rape, Maria's noncombatant character desires to kill Falangists (fascists) and there is no return to a safe and sweet home for her. Contrastingly, for Jordan there is a coming back to America (Carter, 2013, p. 9). This might serve the reason for Maria's 
attachment to Jordan because neither she has a home left to return to, nor does she have enough surety to see the Republic winning and the rapist opponents killed.

For sure, Pilar and Maria's presence in war, their dedication to fighting and their neglecting of the traditional "angel of the cave" brightly proves their resistance to androcentric feminized life-adaptations (Carter, 2013, p. 11). Based on Hemingway's descriptions, Maria who is a semiindependent woman is way ahead of Pilar in rejecting patriarchal codes because she used to be the daughter of a respectful mayor and now she is living in a cave with a band of guerillas. Contrastingly, Pilar who occupied a much less privileged lifestyle looks more independent than Maria. The appearance of both of these characters magnifies not only their present status as insurgents but also their past and their hide-bound conduct.

\section{4. 2. Address and Agency}

It can be said that the first publicly romantic interactions of Maria and Jordan appears to be vague and not approvingly accepted by their other male warriors and friends. One day after the morning greetings they kiss, and Fernando, one of the guerillas objects to that. He tells Pillar that she should not let Maria have such affairs with men before marriage (Hemingway, 1940, p. 97).

\section{4. 3. Patriarchal Deciding}

Jordan and one of the guerillas named Agustin have a conversation that gradually leads to Jordan's marital status about which he says he is not married. Agustin then mentions Maria and tells Jordan that since Maria joined them, 'Pilar has kept her away from all as fiercely as though she were in a convent of Carmelites ... How does that seem to thee?' And then Jordan replies 'she has put her in my care' (Hemingway, 1940, p. 300). Moreover, Agustin tells Jordan that chastity is a must for women and warns him that 'for this we kill much here' (p. 301).

It seems that, other men in the group also desired Maria but Pilar resisted. Evidently, the only matter of which nobody talks about is Maria's own decisions. Thus, indirectly the men are talking about her as an object to be hunted who was guarded by Pilar, who in spite of being a woman, might carry the label of oppressor, because she does not consider Maria as an intelligent being who is sanely and perfectly able to make decisions. However, it is argued by Hewson (2004) that: 'The affirmations of life and love that Jordan makes as he experiences emotional commitment for the first time with Maria appear symptomatic of
Hemingway's desire to move beyond a restrictive system of sexuality or gender' (p. 173).

\section{5. Patriarchal Woman}

The slave-master behavior between Maria and Pilar is much more visible at first when the guerillas see Maria and bring her to their shelter. During their first moments of acquaintance, Maria could not walk and even speak. But Pilar put a rope around her and forced her along to make her move (Hemingway, 1940, p. 30).

The beating of the traumatized Maria like a slave who has to serve his/her master is the beginning of the later oppressor/victim relationship which is magnified in Maria's relationship with men and Pilar's controlling concerns about it. Nevertheless, Sinclair (2002) observes that 'with Pilar, we emphasize desirable maternal strength, not emasculating force' (p. 94). Although Maria did not have another place to go and her parents were brutally shot by fascist soldiers, Rafael's sexist narration of the story of her arrival in their band appears to be demeaning to a large extent.

There is an obscure matter in the novel about Maria's sexuality and Pilar's part taken in it. While some critics believe that Maria is silenced and sexually objectified by Robert Jordan, some of the others observe that Maria's sexual encounters with Jordan are encouraged by her mother figure, Pilar:

Maria makes a conscious decision, encouraged by Pilar's advice, to give herself sexually to erase choice having been so brutally seized from her before. She is not a submissive woman whose will is nonexistent or twined around a man's, but instead acts positively to assert her own force and to free herself from others' intrusion upon her. I certainly would not argue that Maria is sexually aggressive or dominates her first [and also second] experience with Robert, but she does initiate the action. (Sinclair, 2002, p. 101)

\section{CONCLUSION}

Generally speaking, Mills (2008) claims that 'it is this conflict over interpretation which is at the heart of the analysis of sexism' (p. 73). Language is not a set of fixed and unchanging codes which are availably used by every speaker, rather it is a tool handled by various users differently. Therefore, it should be considered a hardcore task to decide which parts of a text are sexist. Moreover, In Gender and Politeness (2003), Mills discusses that 'literary 
and cultural theory, particularly since poststructuralism, rather than viewing the language production of individuals as a product, have seen language as the site where identity is constructed' (p. 19).

This study has explored "feminine identity" in Hemingway's For Whom the Bell Tolls (1940) and then "the male hectoring" has been taken as an assertive step toward the highlighting of sexism in the novel. It is no surprise that Hemingway's narration of male/female interaction holds a phallocentric resonance because he is a male writer and sees the world from a man's perspective (Hewson, 2004, p. 180). However, the androcentric sexism to which this study has pointed, not only involves women but also men and their gender issues.

Although many sexist remarks exist in the novel, on the other side, no woman is killed in the story while several men including the protagonist face death, doing their androcentric duty. Hemingway's inadvertent glorification of heterosexual love is apparent throughout the novel. He puts emphasis on the necessary existence of a male and female partner to concretize love; a force which would not be conquered even by death. However, the death of Robert Jordan leaves another trauma for Maria who after losing her parents, now has lost her lover (Sinclair, 2002, p. 99).

Some feminist readers might go further and accuse Hemingway of giving the male characters agency to pay much attention to the women of the story in terms of sexual pleasure and erotic love. It should be mentioned that along with the sociology of gender, there is the biology of sex which causes basic social and individual differences in men and women. Thus, it is observed that although there are hypothesized values acquired by men and women in their society, there are also actualized qualities in both of the sexes which govern their conduct (Mills, 2008, p. 130).

As a final caveat, it should be stated that although this study has tried to sketch male hectoring and masculine repressiveness in a novel, the Third wave academic feminist analysis encircles a more local-based study of women, their problems and their involving issues, which would to some extent stop the extrapolation of the ideations and examples mentioned in this article. The major ideology of this study suggests more detailed and locally conducted studies so as to explore and manage female concerns.

\section{REFERENCES}

[1] Ainsworth, S., \& Hardy, C. (2004). Critical Discourse Analysis and identity: why bother?. Critical Discourse Studies, $\quad$ l(2), 225-259. doi.org/10.1080/1740590042000302085

[2] Cameron, D. (Ed.). (1990). The Feminist Critique of Language: A Reader ( $2^{\text {nd }}$ ed.). Retrieved from https://www.worldcat.org/

[3] Carter, N. (2013). 'Always Something of It Remains': Sexual Trauma in Ernest Hemingway's For Whom the Bell Tolls. War, Literature \& the Arts, 25(1), 1-40. Retrieved from http://digitalcommons.butler.edu/facsch_papers/384

[4] Derek, N. (2017). The Gender Continuum in Ernest Hemingway's War Novels. Monarch Review, 4(1), 3-8. Retrieved from https://www.methodist.edu/wpcontent/uploads/2018/09/mr2017_derek.pdf

[5] Donne, J. (1959). Devotions Upon Emergent Occasions: Together with Death's Duel. Retrieved from https://www.gutenberg.org/ (Original work published 1623)

[6] Eby, C. (1998). Rabbit Stew and Blowing Dorothy's Bridges: Love, Aggression, and Fetishism in For Whom the Bell Tolls. Twentieth Century Literature, 44(2), 204218. Retrieved from www.jstor.org/stable/441871

[7] Hemingway, E. (2005). For Whom the Bell Tolls. London, England: Vintage Books. (Original work published 1940)

[8] Hewson, M. (2004). A Matter of Love or Death: Hemingway's Developing Psychosexuality In 'For Whom The Bell Tolls.' Studies in the Novel, 36(2), 170-184. Retrieved from www.jstor.org/stable/29533634

[9] Kern, A. (2005). About Literary Wars. War, Literature \& the Arts: An International Journal of the Humanities, 17(1/2), 146-161. Retrieved from search.ebscohost.com/login.aspx?direct=true \&site=edslive $\& d$ $\mathrm{b}=\mathrm{a} 9 \mathrm{~h} \& \mathrm{AN}=19134295 \&$ custid $=\mathrm{s} 6224580$

[10] Maxwell, L. R. (2016). 'Nothing Can Touch You as Long as You Work': Love and Work in Ernest Hemingway's The Garden of Eden and For Whom the Bell Tolls. European Journal of American Studies, 11(2), 1-19. Retrieved from https://doi.org/10.4000/ejas.11557

[11] Mills, S. (1987). The Male Sentence. Language and Communication, 7(3), 189-198. Retrieved from https://doi.org/10.1016/0271-5309(87)90024-3

[12] Mills, S. (1988). Do Men and Women Talk Differently?. Language and Communication, 8(2), 155-158. Retrieved from https://doi.org/10.1016/0271-5309(88)90013-4

[13] Mills, S. (1990). M/Otherland. Cultural Studies, 4(2), 195198. $\quad$ Retrieved from https://doi.org/10.1080/09502389000490161

[14] Mills, S. (2003). Gender and Politeness. Retrieved from www.megapaper.ir

[15] Mills, S. (2008). Language and Sexism. Retrieved from www.megapaper.ir

[16] Sinclair, G. D. (2002). Revisiting the Code: Female Foundations and 'The Undiscovered Country' in For Whom 
the Bell Tolls. In L. R. Broer \& G. Holland (Eds.), Hemingway and Women: Female Critics and the Female Voice. (pp. 93-108). Retrieved from https://www.mobt3ath.com/uplode/book/book-62891.pdf

[17] Van der Bom, I., \& Mills, S. (2018). Interview with Sara Mills. Journal of Language and Discrimination, 2(1), 124128. Retrieved from https://doi.org/10.1558/jld.36207 